\title{
Ozone risk for vegetation in the future climate of Europe based on stomatal ozone uptake calculations
}

\author{
By J. KLINGBERG ${ }^{1 *}$, M. ENGARDT ${ }^{2}$, J. UDDLING ${ }^{1}$, P.E. KARLS SON ${ }^{3}$ and H. PLEIJEL ${ }^{1}$, \\ ${ }^{1}$ Department of Plant and Environmental Sciences, University of Gothenburg, P.O. Box 461, SE-40530 \\ Gothenburg, Sweden; ${ }^{2}$ Swedish Meteorological and Hydrological Institute, SE-60176 Norrköping, Sweden; \\ ${ }^{3}$ Swedish Environmental Research Institute, P.O. Box 5302, SE-40014 Gothenburg, Sweden
}

(Manuscript received 18 September 2009; in final form 23 April 2010)

\begin{abstract}
The negative impacts of surface ozone $\left(\mathrm{O}_{3}\right)$ on vegetation are determined by external exposure, leaf gas exchange and plant antioxidant defence capacity, all dependent on climate and $\mathrm{CO}_{2}$ concentrations. In this study the influence of climate change on simulated stomatal $\mathrm{O}_{3}$ uptake of a generic crop and a generic deciduous tree at ten European sites was investigated, using the LRTAP Mapping Manual stomatal flux model. $\mathrm{O}_{3}$ concentrations are calculated by a chemistry transport model (MATCH) for three 30-yr time-windows (1961-1990, 2021-2050, 2071-2100), with constant precursor emissions and meteorology from a regional climate model (RCA3). Despite substantially increased modelled future $\mathrm{O}_{3}$ concentrations in central and southern Europe, the flux-based risk for $\mathrm{O}_{3}$ damage to vegetation is predicted to remain unchanged or decrease at most sites, mainly as a result of projected reductions in stomatal conductance under rising $\mathrm{CO}_{2}$ concentrations. Drier conditions in southern Europe are also important for this result. At northern latitudes, the current parameterisation of the stomatal conductance model suggest $\mathrm{O}_{3}$ uptake to be mainly limited by temperature. This study demonstrates the importance of accounting for the influences by climate and $\mathrm{CO}_{2}$ on stomatal $\mathrm{O}_{3}$ uptake, and of developing their representation in models, for risk assessment involving climate change.
\end{abstract}

\section{Introduction}

Surface ozone $\left(\mathrm{O}_{3}\right)$ is an air pollutant of major concern, causing reduced crop yield and quality, impaired forest growth and negative effects on human health (The Royal Society, 2008). Due to its strong dependence on meteorological conditions, surface $\mathrm{O}_{3}$ is sensitive to climate change (Jacob and Winner, 2009). A number of studies have reported increasing background $\mathrm{O}_{3}$ concentrations over the mid-latitudes of the Northern Hemisphere during the last decades (Vingarzan, 2004; Derwent et al., 2007) and modelling studies indicate a significant rise in global mean $\mathrm{O}_{3}$ concentration in the future unless large emission reductions are implemented (Prather et al., 2003; Dentener et al., 2006; Stevenson et al., 2006). For Europe, regional air quality models, simulating the conditions during future climate, generally show increasing $\mathrm{O}_{3}$ concentrations despite constant anthropogenic precursor emissions (Langner et al., 2005; Meleux et al., 2007; Andersson and Engardt, 2010). The increase is mostly explained by increased temperature, decreased cloudiness (Meleux

\footnotetext{
*Corresponding author.

e-mail: jenny.klingberg@dpes.gu.se

DOI: $10.1111 /$ j.1600-0870.2010.00465.x
}

et al., 2007) and reduced dry deposition (Andersson and Engardt, 2010). Thus, climate change has the potential to counteract emission reductions aimed to limit surface $\mathrm{O}_{3}$ concentrations. This is important to consider in future air quality and emission control policies (Meleux et al., 2007).

Current global yield losses has been estimated to be in the range of 3-16\% for four major food crops due to exposure to surface $\mathrm{O}_{3}$ concentrations, with additional reductions under possible higher $\mathrm{O}_{3}$ concentrations in the future, posing a serious threat to food security (Van Dingenen et al., 2009). However, the negative effects of $\mathrm{O}_{3}$ on vegetation are more closely related to the uptake of $\mathrm{O}_{3}$ through the stomata than to the concentration in the ambient air (Emberson et al., 2000b; Ashmore et al., 2004; Pleijel et al., 2004; Uddling et al., 2004; Karlsson et al., 2007a). Factors influencing the stomatal uptake of $\mathrm{O}_{3}$ therefore have to be considered in risk assessment. A fluxbased index (PODY, phytotoxic $\mathrm{O}_{3}$ dose above a flux threshold $\mathrm{Y}$, earlier called $\mathrm{AF}_{\mathrm{st}} \mathrm{Y}$, accumulated stomatal flux of $\mathrm{O}_{3}$ ) has been developed, which takes into account the influence of temperature, solar radiation, water vapour pressure deficit (VPD), soil water potential (SWP), atmospheric $\mathrm{O}_{3}$ concentration and plant development stage (phenology) on stomatal $\mathrm{O}_{3}$ uptake (LRTAP Convention, 2004; Pleijel et al., 2007). For a given $\mathrm{O}_{3}$ 
concentration, the stomatal flux $\left(\mathrm{O}_{3}\right.$ uptake $)$ will be greater under humid conditions since dry air and soil moisture deficit induce stomatal closure to minimize plant water loss through transpiration. Evaluations have shown the PODY index to be superior to the concentration-based index AOT40 in explaining yield reductions for wheat and potato (Pleijel et al., 2004) as well as biomass reductions and visible leaf injury for $\mathrm{O}_{3}$ sensitive tree species (Uddling et al., 2004; Karlsson et al., 2007a). Unlike the concentration-based index AOT40, the flux-based approach allows modification of $\mathrm{O}_{3}$ sensitivity by climatic conditions to be incorporated into the risk assessment.

Models of stomatal conductance $\left(g_{\mathrm{s}}\right)$ have been parametrized for a limited number of crop and tree species. Within the UNECE LRTAP Convention, a simplified multiplicative $g_{\mathrm{s}}$ model has been developed and employed to quantify stomatal $\mathrm{O}_{3}$ flux and estimate the risk for $\mathrm{O}_{3}$ damage to a generic crop and generic tree species across Europe (LRTAP Convention, 2004; Simpson and Emberson, 2006) to be used in large-scale modelling. Maps of modelled flux-based $\mathrm{O}_{3}$ risk for a generic crop have been shown to better correspond with field-based evidence of adverse affects compared to AOT40 (Hayes et al., 2007).

In assessing future $\mathrm{O}_{3}$ risk for vegetation it is important to consider the reduction of $g_{\mathrm{s}}$ in elevated $\mathrm{CO}_{2}$ concentrations (Ainsworth and Rogers, 2007). Plants do not maximise the $\mathrm{CO}_{2}$ uptake, but rather optimise the water use efficiency to loose as little water as possible per $\mathrm{CO}_{2}$ taken up (Jones, 1992). In higher $\mathrm{CO}_{2}$ concentrations, the optimum water use efficiency tends to be achieved with smaller stomatal opening. In a case study for winter wheat, Harmens et al. (2007) assumed a 35\% reduction in $g_{\mathrm{s}}$ due to elevated $\mathrm{CO}_{2}$ concentrations and modified current (1997) meteorology and $\mathrm{O}_{3}$ concentrations input data to POD6 calculations for five grid squares in the EMEP model. The results showed that with a $3^{\circ} \mathrm{C}$ increase in temperature and constant absolute humidity, the absorbed $\mathrm{O}_{3}$ dose decreased, despite an assumed $5 \mathrm{ppb}$ increase in $\mathrm{O}_{3}$ concentrations. The result is however based on simplified assumptions of the future climate. Sitch et al. (2007) estimated the impact of projected $\mathrm{O}_{3}$ concentrations on the land-carbon sink, by including the effect of $\mathrm{O}_{3}$ deposition on photosynthesis and the interactions between $\mathrm{O}_{3}$ and $\mathrm{CO}_{2}$ through stomatal closure in their global land-carbon cycle model. Their results suggest a significant suppression of the global land-carbon sink due to negative effects of $\mathrm{O}_{3}$ on plant productivity. $\mathrm{CO}_{2}$-induced stomatal closure was found to offset the $\mathrm{O}_{3}$ suppression of gross primary production by more than one third. Hence, the combined effects of climatic conditions and elevated $\mathrm{CO}_{2}$ concentrations on future $\mathrm{O}_{3}$ risk for vegetation are important for future crop and forest production and should be accounted for in coupled biosphere-climate models.

In this study, $\mathrm{O}_{3}$ concentrations from a regional chemistry transport model (MATCH), driven by meteorological data from a regional climate model (RCA3), was used to estimate reference (1961-1990), near future (2021-2050) and far future
(2071-2100) flux-based $\mathrm{O}_{3}$ risk (PODY) in Europe using the Mapping Manual stomatal flux model (LRTAP Convention, 2004). Anthropogenic precursor emissions and boundary concentrations were held constant in the chemistry transport model, in order to limit the investigation to the influence of climate change.

The aims of the study were:

- To assess the influence of climate change and elevated $\mathrm{CO}_{2}$ concentrations on the flux-based risk for $\mathrm{O}_{3}$ damage to a generic crop and a generic deciduous tree in Europe. The hypotheses were that even without changes in $\mathrm{O}_{3}$ precursor emissions, climate change could significantly modify the flux-based $\mathrm{O}_{3}$ risk and that the plant stomatal response to elevated $\mathrm{CO}_{2}$ concentrations would have the potential to significantly reduce the $\mathrm{O}_{3}$ risk.

- To describe the spatial differences in the modelled reference and future flux-based risk at ten sites along a transect from northeast to southwest in Europe. The hypothesis was that dry air and high soil moisture deficit would substantially limit stomatal flux of $\mathrm{O}_{3}$ in the south, while low temperatures would be limiting in the north.

- To compare the flux-based risk assessment with that based on AOT40. The hypothesis was that AOT40 would predict a relatively smaller risk in the northern part of Europe and larger risk in the southern part of Europe in both reference and future climate, compared to the flux-based risk assessment.

\section{Methods}

\subsection{Stomatal $\mathrm{O}_{3}$ flux}

The stomatal $\mathrm{O}_{3}$ flux was calculated using a multiplicative algorithm (an extension of the concepts presented in Jarvis (1976), Emberson et al. (2000a) and Emberson et al. (2000b)), which includes functions accounting for the limiting effects of various abiotic factors on stomatal conductance, thereby regulating the $\mathrm{O}_{3}$ flux into the plant leaf. The multiplicative algorithm is (LRTAP Convention, 2004)

$$
\begin{aligned}
g_{\mathrm{s}}= & g_{\max } \times\left[\min \left(f_{\mathrm{phen}}, f_{\mathrm{O}_{3}}\right)\right] \times f_{\text {light }} \\
& \times \max \left\{f_{\text {min }},\left(f_{\text {temp }} \times f_{\mathrm{VPD}} \times f_{\mathrm{SWP}}\right)\right\},
\end{aligned}
$$

where $g_{\mathrm{s}}$ is the stomatal conductance $\left[\mathrm{mmol} \mathrm{O}_{3} \mathrm{~m}^{-2}\right.$ sunlit projected leaf area (PLA) $\mathrm{s}^{-1}$ ] and $g_{\max }$ is the species-specific maximum $g_{\mathrm{s}}$. The functions $f_{\text {phen }}, f_{\mathrm{O}_{3}}, f_{\text {light }}, f_{\text {temp }}, f_{\mathrm{VPD}}$ and $f_{\mathrm{SWP}}$ are expressed in relative terms (take values between 0 and 1) as a proportion of $g_{\max }$. These parameters allow for the influence of phenology and $\mathrm{O}_{3}$, and the environmental variables (irradiance, temperature, water VPD and SWP) on $g_{\mathrm{s}}$ to be estimated. The part of eq. (1) related to $f_{\text {phen }}$ and $f_{\mathrm{O}_{3}}$ is a most limiting factor approach; i.e. $g_{\mathrm{s}}$ is limited by either senescence due to normal aging or premature senescence induced by $\mathrm{O}_{3}$. 
The stomatal flux $\left(F_{\mathrm{st}}\right)$ of $\mathrm{O}_{3}$ to a plant leaf is calculated using a resistance analogue

$F_{\mathrm{st}}=C(z) \times \frac{1}{r_{b}+r_{c}} \times \frac{g_{\mathrm{s}}}{g_{\mathrm{s}}+g_{\mathrm{ext}}}$.

The $\mathrm{O}_{3}$ concentration at the top of the canopy $[\mathrm{C}(z)]$ is assumed to be a reasonable estimate of the concentration at the surface of the laminar leaf boundary layer near the sunlit upper canopy leaves. The $1 /\left(r_{b}+r_{c}\right)$ term is the deposition rate to the leaf determined by the quasi-laminar resistance $\left(r_{b}\right)$ and the leaf surface resistance $\left(r_{c}\right) g_{\mathrm{s}} /\left(g_{\mathrm{s}}+g_{\text {ext }}\right)$ represents the fraction of $\mathrm{O}_{3}$ taken up through the stomata, where $1 / g_{\text {ext }}$ is the external leaf resistance.

The POD accumulated per unit projected sunlit leaf area above a threshold of $\mathrm{Y} \mathrm{nmol} \mathrm{m} \mathrm{m}^{-2} \mathrm{~s}^{-1}$ was calculated as

PODY $=\int \max \left(F_{s t}-Y, 0\right) \mathrm{d} t$.

The PODY is accumulated over a period of time corresponding to the part of the growing season when the plant is considered to be sensitive to $\mathrm{O}_{3}$.

In this study a simplified flux-based method, recommended for large-scale modelling (LRTAP Convention, 2004; Simpson and Emberson, 2006) was used to indicate the risk for $\mathrm{O}_{3}$ damage to a generic crop (POD3 $3_{\text {crop }}$ ) and a generic deciduous tree (POD1.6 $6_{\text {tree }}$ ). Important simplifications were that $\mathrm{O}_{3}$-induced premature senescence was assumed to have no effect on $g_{\mathrm{s}}$ (i.e. $f_{\mathrm{O}_{3}}=1$ ) and that a lower threshold were used for the generic crop than recommended by the LRTAP Convention (2004) for specific crops $\left(Y=3 \mathrm{nmol} \mathrm{m}{ }^{-2}\right.$ PLA s $^{-1}$ for a generic crop compared to $Y=6 \mathrm{nmol} \mathrm{m}^{-2}$ PLA s$^{-1}$ for wheat and potato), making the method numerically more robust (Tuovinen et al., 2007). The threshold for trees is $Y=1.6 \mathrm{nmol} \mathrm{m}^{-2} \mathrm{PLA} \mathrm{s}^{-1}$. For a generic crop a 3-month time-window for stomatal $\mathrm{O}_{3}$ flux accumulation based on latitude (LRTAP Convention, 2004), was used to bypass the uncertainty in the timing of the relevant timeinterval, which, especially for crops, is rather short. The start and length of the generic deciduous tree stomatal $\mathrm{O}_{3}$ accumulation period was based on latitude and altitude (LRTAP Convention, 2004). Due to uncertainties caused by difficulties in modelling a plant-relevant SWP, the potentially large variations in soil moisture within a model grid and possible irrigation practices, soil moisture was assumed not to limit $g_{\mathrm{s}}$ (i.e. $f_{\mathrm{SWP}}=1$ ). In one PODY calculation for the generic deciduous tree, however, a SWP function was included to estimate the potential influence of this factor on $g_{\mathrm{s}}$ and the stomatal $\mathrm{O}_{3}$ flux. It was assumed that water was freely available from 0 to $-0.05 \mathrm{MPa}$ SWP with a linear decrease in water availability (and $g_{\mathrm{s}}$ ) below $-0.05 \mathrm{MPa}$ down to a minimum at $-1.5 \mathrm{MPa}$ SWP (Hall et al., 1977). The stomatal flux algorithm and the parameterisation of the simplified fluxbased method for a generic crop and a generic deciduous tree are further described in the LRTAP Convention (2004).

\subsection{The $\mathrm{CO}_{2}$ function}

Several studies have shown reduced $g_{\mathrm{s}}$ (on average 0.66 of that in $370 \mathrm{ppm} \mathrm{CO}_{2}$ ) for wheat grown in $550-570 \mathrm{ppm} \mathrm{CO}_{2}$ concentrations (Wall et al., 2000, 2006). For wheat grown in 700 ppm $\mathrm{CO}_{2}$, the average $g_{\mathrm{s}}$ ratio at elevated to ambient ( $\sim 350 \mathrm{ppm}$ during daytime) $\mathrm{CO}_{2}$ was 0.56 (Bunce, 2000). In a meta-analysis, Ainsworth and Rogers (2007) found the reduction in stomatal conductance of $\mathrm{C}_{3}$ crops to be $25 \%$ in $567 \mathrm{ppm} \mathrm{CO}_{2}$ compared to ambient (366 ppm) and Pleijel et al. (2002) found up to a $20 \%$ reduction in $g_{\mathrm{s}}$ for potato grown in $680 \mathrm{ppm} \mathrm{CO}_{2}$ compared to $360 \mathrm{ppm}$. Ainsworth and Rogers (2007) also found a 19\% reduction of $g_{\mathrm{s}}$ in trees grown in elevated $\mathrm{CO}_{2}$ concentrations (567 ppm on average) compared to ambient $\mathrm{CO}_{2}$ concentrations (366 ppm on average). Medlyn et al. (2001) reported a $21 \%$ decrease in $g_{\mathrm{s}}$ for trees in response to growth in $700 \mathrm{ppm} \mathrm{CO}_{2}$ compared to $350 \mathrm{ppm} \mathrm{CO}_{2}$. Based on these studies, $\mathrm{CO}_{2}$ response functions $\left(f_{\mathrm{CO}_{2}}\right)$ for a generic crop and a generic deciduous tree were parametrized and added to eq. (1). The influence of increasing $\mathrm{CO}_{2}$ on $g_{\mathrm{s}}$ was, in this study, assumed to linearly decrease between 360 and $560 \mathrm{ppm} \mathrm{CO}_{2}$ concentration from 1 to 0.66 for a generic crop and to 0.8 for a generic deciduous tree, with no further reductions in $g_{\mathrm{s}}$ above $560 \mathrm{ppm} \mathrm{CO}_{2}$ (Fig. 1). However, there is a large uncertainty with respect to the effect of elevated $\mathrm{CO}_{2}$ on $g_{\mathrm{s}}$ in closed forest stands (Uddling et al., 2009 and references therein). Because of this uncertainty, the possible effect of $\mathrm{CO}_{2}$ on PODY was explored as a sensitivity study, by performing the calculations with and without inclusion of $f_{\mathrm{CO}_{2}}$. This was done also for the generic crop in order to separate effects of climatic changes from effects of rising $\mathrm{CO}_{2}$ concentrations on stomatal $\mathrm{O}_{3}$ flux.

\subsection{MATCH and RCA3 model set-up and PODY input data}

MATCH is a Eulerian, off-line, regional chemistry transport model. A detailed description of the model is available in Robertson et al. (1999). A number of previous studies have demonstrated the ability of MATCH to realistically simulate $\mathrm{O}_{3}$ concentrations over Europe (e.g. Tilmes et al., 2002; Andersson et al., 2007; van Loon et al., 2007). In order to investigate the effect of future climate change on surface $\mathrm{O}_{3}, \mathrm{MATCH}$ was driven by meteorology from the Rossby Centre's regional climate model (RCA3), described in Kjellström et al. (2005). In this study RCA3 was forced with climate data from the ECHAM4/OPYC3 global model on its boundaries simulating the IPCC SRES A2 and B2 emission scenarios (Nakicenovic et al., 2000). A2 is one of the more pessimistic greenhouse gas emission scenarios. The two emission scenarios yield similar climate change evolution for the first half of the 21 st century, but in the second half of the 21 st century there is an increasingly larger signal in the $\mathrm{A} 2$ scenario. The canopy-scale $\mathrm{O}_{3}$ dry deposition to vegetation in MATCH is a function of soil moisture, air humidity, temperature and irradiance. Also, emissions 
Fig. 1. The influence of atmospheric $\mathrm{CO}_{2}$ concentrations on stomatal conductance for a generic crop (GEN-C) and for a generic deciduous tree (GEN-DT). Relative stomatal conductance $\left(f_{\mathrm{CO}_{2}}\right)$ in relation to (a) $\mathrm{CO}_{2}$ concentration and (b) year using the $\mathrm{A} 2$ emission scenario. The data points in (a) are the observations on which the $\mathrm{CO}_{2}$ functions were based, see Section 2.2 for references.
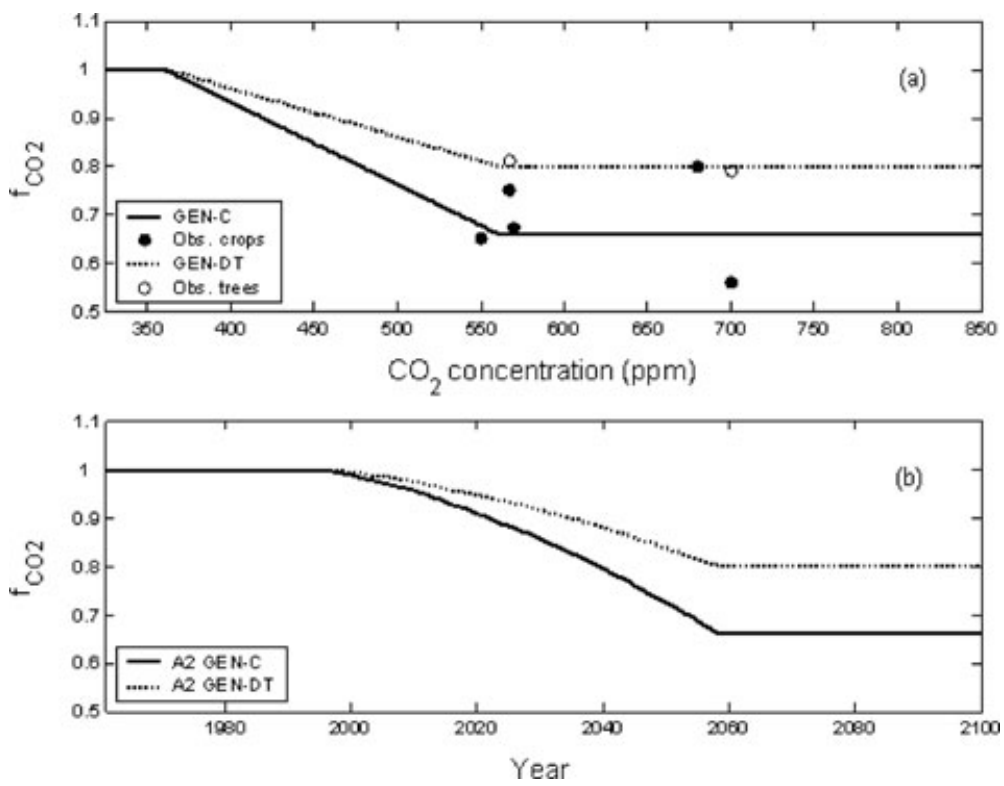

of biogenic isoprene are calculated online in MATCH. Natural emissions of other VOCs, sulphur or nitrogen containing compounds are not included in the present set-up. Hence, modelled future $\mathrm{O}_{3}$ concentrations are affected by changes in photochemistry, transport patterns, emissions and uptake by vegetation. Anthropogenic emissions and tracer boundary concentrations were set constant in MATCH, representing the year 2000, in order to isolate the influence of climate change and not changes in emission patterns. In MATCH three 30-yr periods were simulated: reference (1961-1990), near future (2021-2050) and far future (2071-2100). The set-up of the model system is further described in Andersson and Engardt (2010). To test if average PODY for the far future (A2 emission scenario) was significantly different compared the reference period, a two-sided Student's $t$-test was applied, assuming unequal variances, with 58 degrees of freedom $(2 \times N-2 ; N=30 \mathrm{yr})$.

For risk assessment purposes it is the stomatal flux of $\mathrm{O}_{3}$ to the sunlit leaf level of specified vegetation types and not the canopy-scale flux that is important. The PODY was, in this study, calculated off-line for a generic crop and a generic deciduous tree at 10 sites based on modelled data from the corresponding grid-cell in MATCH $\left(\mathrm{O}_{3}\right)$ and RCA3 (meteorology). The ten monitoring sites within the European Monitoring and Evaluation Programme (EMEP) within CLRTAP were selected in a transect from northeast to southwest to represent different climatic conditions in Europe. Site characteristics and estimated growing seasons can be found in Table 1 and site locations in Fig. 2 which also shows the modelled April to September average daily maximum $\mathrm{O}_{3}$ in reference climate (1961-1990). PODY was calculated for both a generic crop and a generic deciduous tree at all sites although, for example, wheat is presently not a suitable crop at the northernmost site. However, the distribution of crops and trees are likely to change in response to climate changes.

$\mathrm{O}_{3}$ and meteorological input data for the PODY calculations should be valid for the height of the canopy which is assumed to be $1 \mathrm{~m}$ above ground level for a generic crop and $20 \mathrm{~m}$ for a generic deciduous tree. In MATCH, the $\mathrm{O}_{3}$ concentrations representing the lowest model layer were downscaled to $3 \mathrm{~m}$ at every time-step based on local stability and surface deposition velocity using similarity theory. To avoid systematic errors, a further correction was applied to adjust the $3 \mathrm{~m} \mathrm{O}_{3}$ concentrations from MATCH to canopy height. Since values of $\mathrm{u}^{*}$ and canopy-scale deposition to vegetation in MATCH were not available (not saved as output data), the simplified method in the Mapping Manual (LRTAP Convention, 2004) was used, assuming that the $\mathrm{O}_{3}$ concentration at $1 \mathrm{~m}$ was $93 \%$ of the $3 \mathrm{~m}$ concentration and that the $\mathrm{O}_{3}$ concentration at $20 \mathrm{~m}$ was $105 \%$ of the $3 \mathrm{~m}$ concentration). Modelled wind speed ( $3 \mathrm{~h}$ resolution, from RCA3) at $10 \mathrm{~m}$ was adjusted to canopy height using the logarithmic wind law, assuming neutral stability. Canopy height wind speed was used to estimate the leaf boundary layer resistance required in the flux calculation. Modelled temperature and relative humidity (from RCA3) corresponding to $2 \mathrm{~m}$ had $3 \mathrm{~h}$ temporal resolution. Linear interpolation was applied to receive the hourly temporal resolution needed for the PODY calculations. Incoming short-wave radiation data with $30 \mathrm{~min}$ resolution was recalculated to photosynthetic photon flux density (PPFD) by multiplying with a factor of 2 (Monteith and Unsworth, 2008). Soil water content summed over the top two soil layers in RCA3 (2.3 m) with six hour resolution was recalculated to SWP using the Groenevelt-Grant soil water retention model 
Table 1. Site coordinates and characteristics according to the EMEP website (www.emep.int/) and soil texture class given by RCA3

\begin{tabular}{|c|c|c|c|c|c|c|}
\hline Site & Country & $\begin{array}{l}\text { Latitude } \\
\text { Longitude }\end{array}$ & $\begin{array}{l}\text { Altitude } \\
\text { (m a.s.l.) }\end{array}$ & $\begin{array}{l}\text { GEN-C growing season } \\
\text { (day number) }\end{array}$ & $\begin{array}{l}\text { GEN-DT growing season } \\
\text { (day number) }\end{array}$ & $\begin{array}{l}\text { Soil texture class } \\
\text { (RCA3) }\end{array}$ \\
\hline FI22 & N Finland & $\begin{array}{l}66^{\circ} 19^{\prime} \mathrm{N} \\
29^{\circ} 24^{\prime} \mathrm{E}\end{array}$ & 310 & $165-254$ & $133-261$ & Sandy loam \\
\hline FI37 & S Finland & $\begin{array}{l}62^{\circ} 33^{\prime} \mathrm{N} \\
24^{\circ} 13^{\prime} \mathrm{E}\end{array}$ & 162 & $154-243$ & $125-271$ & Sandy loam \\
\hline SE32 & S Sweden & $\begin{array}{l}57^{\circ} 49^{\prime} \mathrm{N} \\
15^{\circ} 34^{\prime} \mathrm{E}\end{array}$ & 261 & $144-233$ & $120-278$ & Sand \\
\hline SE11 & S Sweden & $\begin{array}{l}56^{\circ} 01^{\prime} \mathrm{N} \\
13^{\circ} 09^{\prime} \mathrm{E}\end{array}$ & 172 & $139-228$ & $116-283$ & Loam \\
\hline DE02 & N Germany & $\begin{array}{l}52^{\circ} 48^{\prime} \mathrm{N} \\
10^{\circ} 45^{\prime} \mathrm{E}\end{array}$ & 74 & $131-220$ & $111-290$ & Sand \\
\hline DE03 & S Germany & $\begin{array}{l}47^{\circ} 55^{\prime} \mathrm{N} \\
7^{\circ} 54^{\prime} \mathrm{E}\end{array}$ & 1205 & $118-207$ & $115-288$ & Loam \\
\hline FR10 & C France & $\begin{array}{l}47^{\circ} 16^{\prime} \mathrm{N} \\
4^{\circ} 05^{\prime} \mathrm{E}\end{array}$ & 620 & $116-205$ & $107-296$ & Silt loam \\
\hline FR13 & S France & $\begin{array}{l}43^{\circ} 37^{\prime} \mathrm{N} \\
0^{\circ} 11^{\prime} \mathrm{E}\end{array}$ & 236 & 106-195 & $97-308$ & Silt loam \\
\hline ES09 & N Spain & $\begin{array}{l}41^{\circ} 16^{\prime} \mathrm{N} \\
3^{\circ} 08^{\prime} \mathrm{W}\end{array}$ & 1360 & $100-189$ & $106-301$ & Loam \\
\hline ES07 & S Spain & $\begin{array}{l}37^{\circ} 14^{\prime} \mathrm{N} \\
3^{\circ} 28^{\prime} \mathrm{W}\end{array}$ & 1230 & 90-179 & $98-310$ & Silt loam \\
\hline
\end{tabular}

Note: The growing season for a generic crop (GEN-C) is based on latitude and the growing season for a generic deciduous tree (GEN-DT) is based on latitude and altitude (LRTAP Convention, 2004).

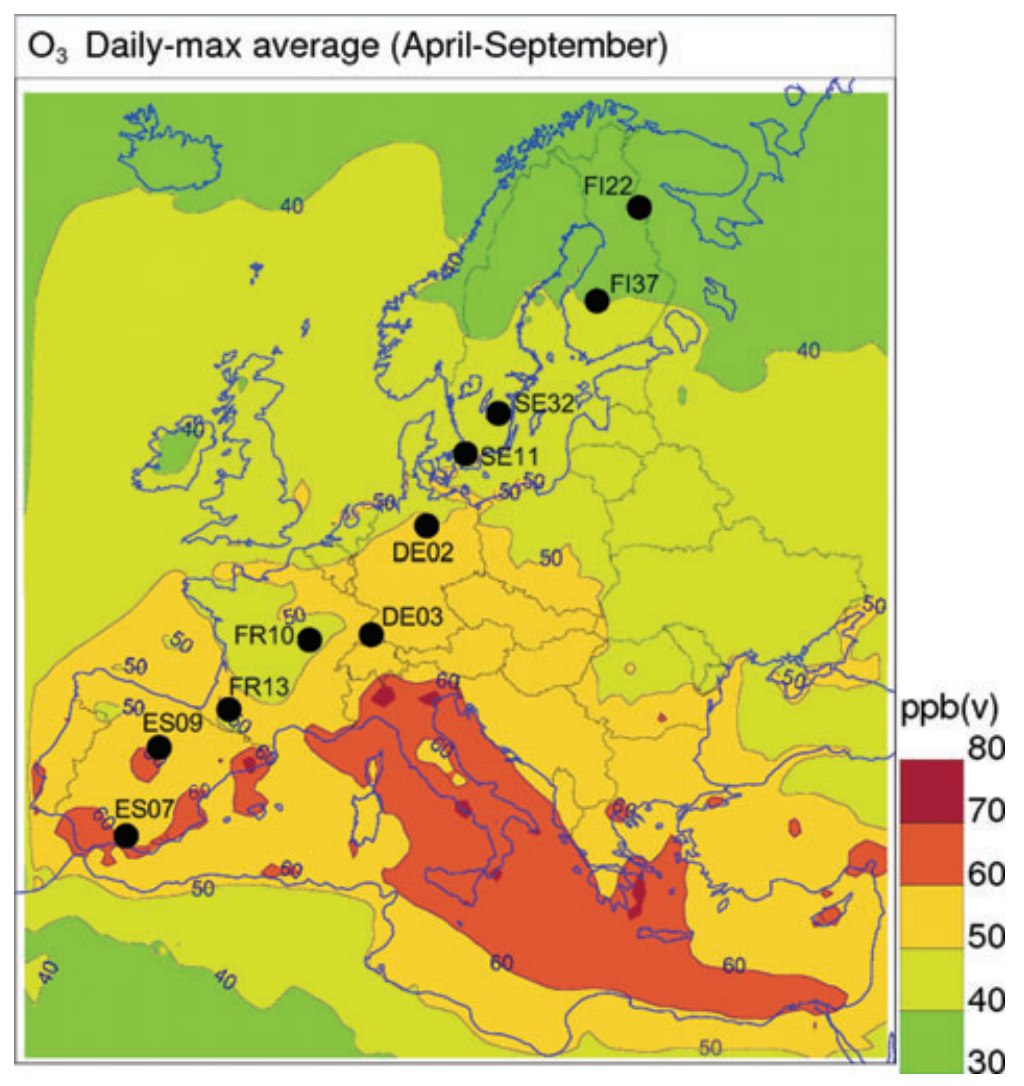

Fig. 2. Location of the ten EMEP sites considered in the PODY calculations. Also shown is the modelled average summer-time (April-September) daily maximum $\mathrm{O}_{3}$ in reference climate (1961-1990). 
(Groenevelt and Grant, 2004) anchored in the point of saturation (Grant et al., 2010)

$\theta(h)=\theta_{s}-k_{1}\left\{\exp \left(\frac{k_{0}}{h}\right)^{n}\right\}$

where $\theta$ is the relative water content $\left(\mathrm{m}^{3} \mathrm{~m}^{-3}\right), \theta_{s}$ is the relative water content at the point of saturation $\left(\mathrm{m}^{3} \mathrm{~m}^{-3}\right)$ and $h$ is the matric suction (m). $k_{0}, k_{1}$ and $n$ are freely adjustable fitting parameters. Values of the parameters used to fit 20 Dutch soils to the Groenevelt-Grant model (Grant et al., 2010) was used for the soil types most similar to those in RCA3 (see Table 1).

\subsection{Comparison of simulations and observations}

The MATCH-RCA3 performance have earlier been evaluated and shown good agreement with $\mathrm{O}_{3}$ concentrations measured at EMEP stations in Europe (Engardt et al., 2009; Andersson and Engardt, 2010). The bias for summer and yearly average and daily maximum concentrations was within $\pm 10 \%$ and correlations were $0.66-0.90$. In this study, average and daily maximum $\mathrm{O}_{3}$ concentrations during the generic crop $\mathrm{O}_{3}$ accumulation period were used to estimate the performance of the MATCHRCA3 modelling system for the ten selected EMEP monitoring sites. Modelled $3 \mathrm{~m} \mathrm{O}_{3}$ concentrations from the last $10 \mathrm{yr}$ of the reference period (i.e.1981-1990) were compared to $\mathrm{O}_{3}$ measurements during 1995-2006. The measurements were centred around the year of precursor emissions used in MATCH (year 2000). Only years with less than $10 \%$ missing data during the generic crop-growing season were included. The (spatial) correlations were high, 0.60 for average $\mathrm{O}_{3}$ and 0.85 for daily maximum, and the average bias small $(+1.5 \%$ bias of average $\mathrm{O}_{3}$ and $-3.7 \%$ bias of the daily maximum).

Hourly temperature and VPD from RCA3 (1981-1990) were compared to the surface analysis (1998-2005) from a high resolution $(11 \mathrm{~km})$ analysis system (MESAN, Häggmark et al., 2000). MESAN-data were only available for the five northernmost sites (FI22, FI37, SE32, SE11 and DE02). Comparison of data from the generic crop $\mathrm{O}_{3}$ accumulation period showed a good agreement of average temperature from RCA3 $(-2.5 \%$ bias in ${ }^{\circ} \mathrm{C}$ ) but consistently smaller range and standard deviation. The 90-percentile temperature was $3.2^{\circ} \mathrm{C}$ lower in RCA3 compared to the surface analysis on average. Since high VPD occurs at high temperatures, the underestimation in temperature results in a large VPD underestimation ( $-43 \%$ bias on average). An explanation could be smaller diurnal variation in the regional scale RCA3 compared to the surface analysis with higher resolution and a better capture of local scale processes. The large underestimation of VPD may cause overestimation of $g_{\mathrm{s}}$ and stomatal $\mathrm{O}_{3}$ flux. The sensitivity of the calculation of POD $3_{\text {crop }}$ due to underestimated VPD input data was analysed by the calculation of the percentage change in the POD $3_{\text {crop }}$ index caused by a $50 \%$ increase in the modelled VPD from RCA3. Modelled temperature, VPD and $\mathrm{O}_{3}$ used for the PODY calculations are shown in Fig. 3.

\section{Results}

\subsection{Concentration-based versus flux-based risk for $\mathrm{O}_{3}$ damage to a generic crop}

In general, model calculated $\mathrm{O}_{3}$ concentrations increase towards southern Europe (Fig. 2). The concentration-based AOT40 index, calculated for daylight hours during the 3 months corresponding to the generic crop growing season (Fig. 4), indicates a higher $\mathrm{O}_{3}$ risk in southern compared to northern Europe. Already in the reference climate the current AOT40 critical level of 3 ppm h (LRTAP Convention, 2004) is exceeded at many sites. Note, however, that the 3 month growing season depends on latitude in this study, which can differ from the May-July AOT40, used e.g. in EU directives for vegetation risk assessments. At 6 of the 10 sites investigated, there is a large increase in future AOT40, especially in the 2071-2100 A2 emission scenario, where five sites (DE03, FR10, FR13, ES09 and ES07) will experience more than a doubling of AOT40. The four Nordic sites (FI22, FI37, SE32 and SE11) exhibit small changes in AOT40. Since emissions were held constant during the simulations, the increase in $\mathrm{O}_{3}$ concentration is entirely due to changes in the climate. The increase in southern Europe $\mathrm{O}_{3}$ concentrations has been explained by reduced dry deposition caused by a changed climate affecting the uptake to vegetation, while increasing isoprene emissions played a minor role (Andersson and Engardt, 2010).

The geographical pattern of the generic crop POD $3_{\text {crop }}$ is considerably different compared to that of AOT40 (Fig. 5). Both in reference and future climate, the stomatal $\mathrm{O}_{3}$ flux is largest in central Europe. The reduction in $g_{\mathrm{s}}$ is $34 \%$ in the 2071-2100 A2 period due to $\mathrm{CO}_{2}$ concentrations above 550 ppm (Fig. 1). As a result, the sites with the largest increase in AOT40 by 2071-2100 in the A2 emission scenario show non-significant changes in POD3 $3_{\text {crop }}$ (DE03 and FR10) or a large decrease in POD $3_{\text {crop }}$ (statistically significant with $p<0.0001$ for FR13, ES09 and ES07). In the same period, the two Swedish sites show a small but significant increase in POD $3_{\text {crop }}(p=0.0119$ for SE32 and $p=0.0268$ for SE11). The same geographical pattern and direction of changes are found for $\mathrm{PODO}_{\text {crop }}$ (data not shown), indicating that the result is not dependent on the choice of threshold.

At the northern sites the $\mathrm{O}_{3}$ concentration is low and the temperature function significantly limits the $g_{\mathrm{s}}$ (average $f_{\text {temp }}$ substantially below 1, see Table 2). With no inclusion of $f_{\mathrm{CO}_{2}}$, POD 3 crop increase significantly at the Nordic sites in the 2071-2100 A2 period compared to the reference period ( $p<$ 0.0001 for FI22, FI37, SE32 and SE11). The increase can be explained by higher temperatures and, for SE11, to some extent higher $\mathrm{O}_{3}$ concentrations. For example, at the northernmost 

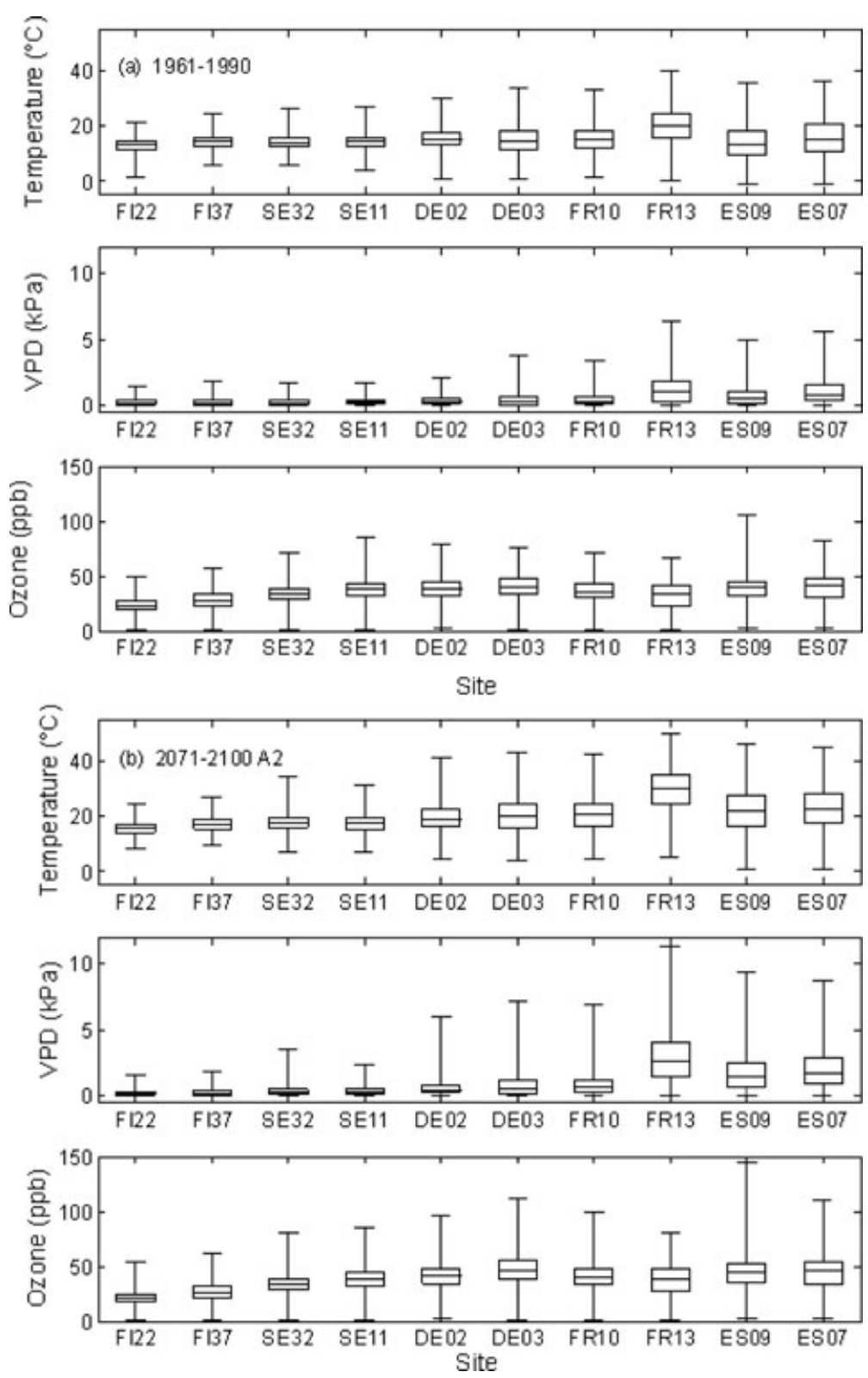

Fig. 3. Box- and whisker plots of the RCA3 and MATCH data for the accumulation period of the generic crop used as input in the stomatal conductance model during (a) 1961-1990 and (b) 2171-2100 using the SRES A2 emission scenario. site (FI22) the average $f_{\text {temp }}$ in reference climate is only 0.24 but increase to 0.49 in 2071-2100 A2, while the average VPD influence on stomatal conductance does not change (average $f_{\mathrm{VPD}}$ does not fall below 1.00 in reference or future climate, see Table 2). Without the influence of $f_{\mathrm{CO}_{2}}, \mathrm{POD} 3_{\text {crop }}$ more than double at FI22 while the average $\mathrm{O}_{3}$ concentration decrease by approximately $1 \mathrm{ppb}$.

In central Europe, the $\mathrm{O}_{3}$ concentrations are high and climatic conditions favour stomatal $\mathrm{O}_{3}$ uptake. The large increase in $\mathrm{O}_{3}$ concentrations by 2071-2100 A2, together with considerably higher $f_{\text {temp }}$, but only slightly lower $f_{\mathrm{VPD}}$ (Table 2) result in a significantly increased stomatal $\mathrm{O}_{3}$ flux compared to reference climate ( $p<0.0001$ for DE02, DE03 and FR10), when $f_{\mathrm{CO}_{2}}$ is not included in the calculation.

As shown in Table 2, $f_{\mathrm{VPD}}$ substantially limits the $g_{\mathrm{s}}$ at the three southernmost sites (FR13, ES09 and ES07) already in reference climate. For example, average $f_{\mathrm{VPD}}$ at the southernmost site (ES07) is 0.75 compared to 1.00 at the site with largest POD 3 crop (DE02). Even without the inclusion of $f_{\mathrm{CO}_{2}}$, the stomatal $\mathrm{O}_{3}$ flux does not increase in the future climate, despite a large increase in $\mathrm{O}_{3}$ concentration (5 ppb on average) by 2071-2100 A2, due to increased VPD.

The pattern is similar for the B2 emission scenario (see Appendix $\mathrm{S} 1$ in the Supporting Information). The increase in $\mathrm{O}_{3}$ 
Fig. 4. Average 3-month daylight AOT40 (corresponding to the generic crop growing season) at the different sites, based on $\mathrm{O}_{3}$ concentrations at $1 \mathrm{~m}$. Error bars show standard deviation $(N=30 \mathrm{yr})$. Current critical level is $3 \mathrm{ppm} \mathrm{h}$, which is indicated by the horizontal line.
Fig. 5. Average phytotoxic $\mathrm{O}_{3}$ dose for a generic crop (POD3 $3_{\text {crop }}$ ) during 1961-1990, 2021-2050 and 2071-2100 following the SRES A2 emission scenario. The striped part of the bars show average POD $3_{\text {crop }}$ when the $g_{\mathrm{s}}$ response function for $\mathrm{CO}_{2}\left(f_{\mathrm{CO}_{2}}\right)$ is included in the calculation. Error bars show standard deviation $(N=30 \mathrm{yr})$. Circles are average $\mathrm{O}_{3}$ concentration (scale on the right) for the same time periods as POD $3_{\text {crop }}$ is accumulated.

Table 2. Average daylight $f_{\text {temp }}$ and $f_{\mathrm{VPD}}$ for a generic crop during the 30-yr reference period and year 2071-2100 following the SRES A2 emission scenario

\begin{tabular}{lccccc}
\hline & \multicolumn{2}{c}{$1961-1990$} & & \multicolumn{2}{c}{$2071-2100 \mathrm{~A} 2$} \\
\cline { 2 - 3 } Site & $f_{\text {temp }}$ & $f_{\text {VPD }}$ & & $f_{\text {temp }}$ & $f_{\text {VPD }}$ \\
\hline FI22 & 0.24 & 1.00 & 0.49 & 1.00 \\
FI37 & 0.36 & 1.00 & & 0.61 & 1.00 \\
SE32 & 0.34 & 1.00 & & 0.65 & 0.99 \\
SE11 & 0.37 & 1.00 & & 0.65 & 1.00 \\
DE02 & 0.48 & 1.00 & & 0.73 & 0.96 \\
DE03 & 0.46 & 0.98 & & 0.72 & 0.84 \\
FR10 & 0.46 & 0.99 & & 0.74 & 0.87 \\
FR13 & 0.58 & 0.85 & & 0.70 & 0.53 \\
ES09 & 0.47 & 0.88 & 0.72 & 0.56 \\
ES07 & 0.59 & 0.75 & 0.77 & 0.44 \\
\hline
\end{tabular}

concentration at the five southernmost sites is smaller than in the $\mathrm{A} 2$ emission scenario (2.7 ppb difference between the 2071-2100 B2 and the reference period, compared to $5.3 \mathrm{ppb}$ in A2). The $f_{\mathrm{VPD}}$ does not limit $g_{\mathrm{s}}$ at the southernmost sites
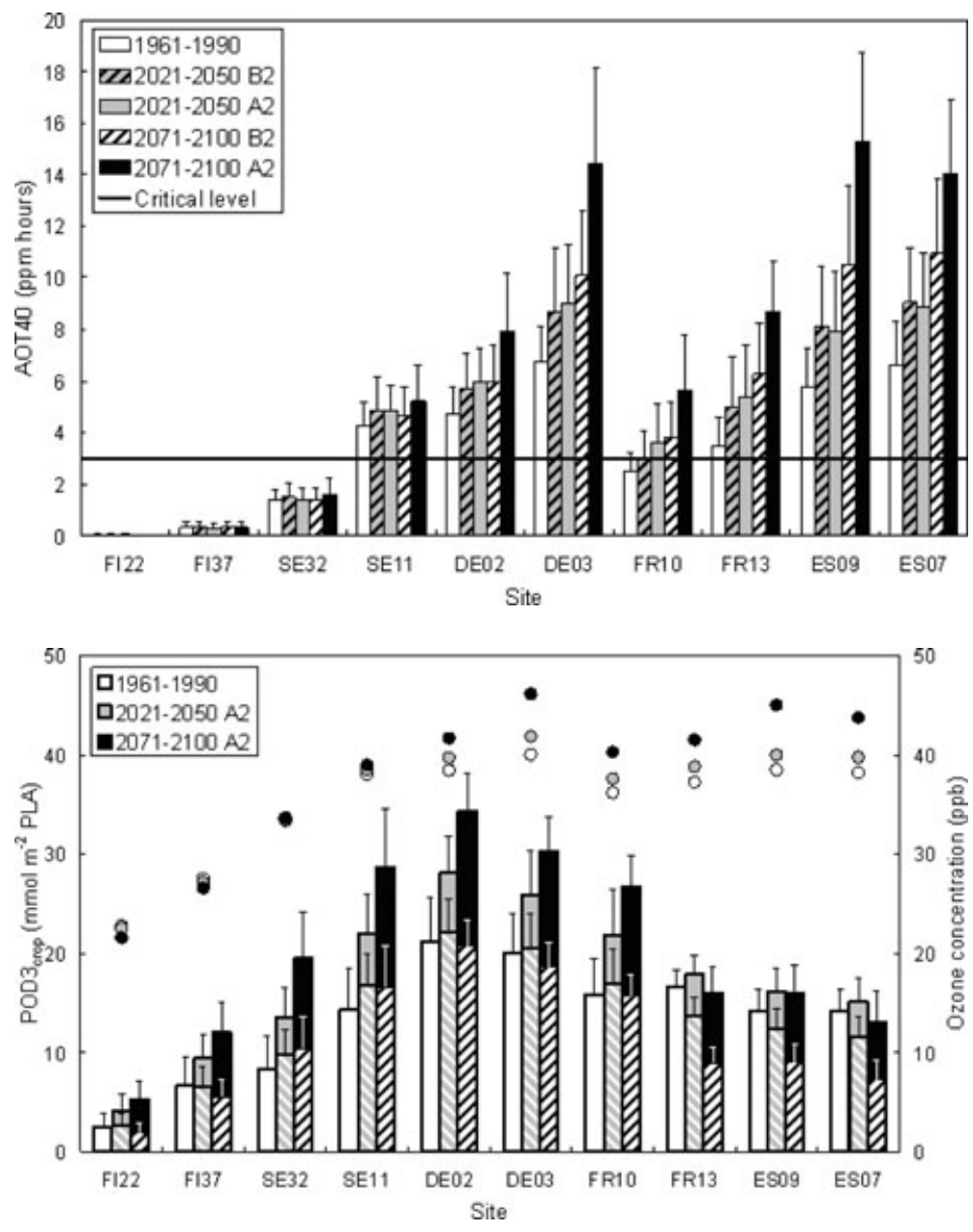

to the same extent, while the increase in $g_{\mathrm{s}}$ due to increasing temperature at the northernmost sites is not as large.

The effect of increasing the calculated VPD from RCA3 with $50 \%$ on average daylight $f_{\mathrm{VPD}}$ and POD $3_{\text {crop }}$ is shown in Table 3. The $g_{\mathrm{s}}$ response to elevated $\mathrm{CO}_{2}$ was not included in this calculation. The average $f_{\mathrm{VPD}}$ is mainly influenced at the southern sites in the reference period and the central and southern sites in the 2071-2100 A2 period. The decrease in $f_{\mathrm{VPD}}$ result in a considerable reduction of POD3 $3_{\text {crop }}$ compared to the base calculations at the southern sites. However, the temporal trend and geographical pattern is not affected.

\subsection{Concentration-based versus flux-based risk for $\mathrm{O}_{3}$ damage to a generic deciduous tree}

The spatial pattern of AOT40 calculated over the generic deciduous tree growing season (data not shown) is very similar to that of the generic crop, with large increases in AOT40 at the six southernmost sites, especially for the 2071-2100 A2 period. The spatial pattern of the generic deciduous tree POD1. $6_{\text {tree }}$ following the A2 scenario (Fig. 6) is also similar to that for a generic crop ( $\mathrm{POD}_{\text {crop}}$ ), with largest stomatal $\mathrm{O}_{3}$ flux in central 
Table 3. The effect of increasing the calculated VPD from RCA3 with $50 \%$ on the average daylight $f_{\mathrm{VPD}}$ and average POD $3_{\text {crop }}\left(f_{\mathrm{CO}_{2}}\right.$ not included) for a generic crop during the 30 -yr reference period and year 2071-2100 following the SRES A2 emission scenario

\begin{tabular}{|c|c|c|c|c|c|c|}
\hline \multirow[b]{2}{*}{ Site } & \multicolumn{3}{|c|}{$1961-1990(\mathrm{VPD} \times 1.5)$} & \multicolumn{3}{|c|}{$2071-2100$ A2 $(\mathrm{VPD} \times 1.5)$} \\
\hline & $f_{\mathrm{VPD}}$ & POD $3_{\text {crop }}$ & $\%$ change & $f_{\mathrm{VPD}}$ & POD $3_{\text {crop }}$ & $\%$ change \\
\hline FI22 & 0.99 & 2.2 & -14 & 1.00 & 5.1 & -3 \\
\hline FI37 & 0.99 & 6.2 & -7 & 0.99 & 11.7 & -2 \\
\hline SE32 & 0.99 & 7.9 & -5 & 0.96 & 17.9 & -8 \\
\hline SE11 & 0.99 & 14.0 & -2 & 0.98 & 27.3 & -5 \\
\hline DE02 & 0.98 & 19.7 & -7 & 0.87 & 28.3 & -18 \\
\hline DE03 & 0.92 & 16.0 & -20 & 0.70 & 21.0 & -31 \\
\hline FR10 & 0.96 & 13.6 & -14 & 0.73 & 19.2 & -28 \\
\hline FR13 & 0.70 & 9.5 & -42 & 0.37 & 8.4 & -47 \\
\hline ES09 & 0.73 & 7.2 & -50 & 0.38 & 7.3 & -54 \\
\hline ES07 & 0.55 & 5.6 & -61 & 0.26 & 5.0 & -62 \\
\hline
\end{tabular}

Note: \% change refers to the change in POD $3_{\text {crop }}$ compared to the calculation without the increase in VPD (shown in Fig. 5).

Europe. At all sites POD1.6 $6_{\text {tree }}$ was significantly reduced in the 2071-2100 A2 period compared to the reference period ( $p<$ $0.0001)$ due to the assumed reduction of $g_{\mathrm{s}}$ by $20 \%$ with $\mathrm{CO}_{2}$ concentrations above 550 ppm (Fig.1).

Low and decreasing $\mathrm{O}_{3}$ concentrations as well as low average $f_{\text {temp }}$ (see Table 4) result in small POD1.6 $6_{\text {tree }}$ at the two northernmost sites (FI22 and FI37), and no significant change by 2071-2100 A2 when the influence of $f_{\mathrm{CO}_{2}}$ is not included in the calculation. SE32, SE11 and DE02 experience increased stomatal $\mathrm{O}_{3}$ flux in the 2071-2100 A2 period ( $\left.p<0.0001\right)$ compared to the reference period, due to climate changes, explained by increases in $\mathrm{O}_{3}$ concentration and average $f_{\text {temp }}$.

The $g_{\mathrm{s}}$ of the generic deciduous tree has a lower temperature optimum compared to the generic crop $\left(T_{\mathrm{opt}}=21^{\circ} \mathrm{C}\right.$ instead of $26^{\circ} \mathrm{C}$ ) and at the southernmost sites (FR13, ES09 and ES07) high temperatures limit $g_{\mathrm{s}}$ in 2071-2100 A2. In addition to the
Table 4. Average daylight $f_{\text {temp }}, f_{\mathrm{VPD}}$ and $f_{\mathrm{SWP}}$ for a generic deciduous tree during the 30-yr reference period and year 2071-2100 following the SRES A2 emission scenario

\begin{tabular}{lccccccc}
\hline & \multicolumn{3}{c}{$1961-1990$} & & \multicolumn{3}{c}{$2071-2100 \mathrm{~A} 2$} \\
\cline { 2 - 3 } \cline { 7 - 8 } Site & $f_{\text {temp }}$ & $f_{\text {VPD }}$ & $f_{\text {SWP }}$ & & $f_{\text {temp }}$ & $f_{\text {VPD }}$ & $f_{\text {SWP }}$ \\
\hline FI22 & 0.77 & 1.00 & 0.99 & & 0.88 & 1.00 & 0.99 \\
FI37 & 0.82 & 1.00 & 0.99 & & 0.91 & 1.00 & 0.99 \\
SE32 & 0.83 & 1.00 & 1.00 & & 0.92 & 0.99 & 1.00 \\
SE11 & 0.84 & 1.00 & 1.00 & & 0.94 & 1.00 & 0.98 \\
DE02 & 0.87 & 1.00 & 1.00 & & 0.92 & 0.95 & 0.97 \\
DE03 & 0.88 & 0.97 & 0.96 & & 0.84 & 0.78 & 0.83 \\
FR10 & 0.88 & 0.99 & 0.99 & & 0.85 & 0.81 & 0.79 \\
FR13 & 0.86 & 0.81 & 0.45 & & 0.66 & 0.53 & 0.22 \\
ES09 & 0.85 & 0.80 & 0.80 & & 0.71 & 0.55 & 0.60 \\
ES07 & 0.84 & 0.64 & 0.38 & & 0.64 & 0.44 & 0.20 \\
\hline
\end{tabular}

dry air conditions (low average $f_{\mathrm{VPD}}$, see Table 4) this result in a significantly reduced stomatal $\mathrm{O}_{3}$ flux $(p<0.0001)$ despite a large increase in average $\mathrm{O}_{3}$ concentration even without the inclusion of $f_{\mathrm{CO}_{2}}$ in the calculations. The result for the $\mathrm{B} 2$ emission scenario can be seen in Appendix S2 in the supporting information

To estimate the potential influence of soil moisture, a SWP function was included in one POD1.6 $6_{\text {tree }}$ calculations (Fig. 7). The $g_{\mathrm{s}}$ response to elevated $\mathrm{CO}_{2}$ was not included. The results indicate that $f_{\text {SWP }}$ mainly limit $\mathrm{O}_{3}$ uptake at the southern sites (Table 4). The SWP function is especially limiting at FR13 and ES07.

\section{Discussion}

This study investigated how the changing climatic conditions and elevated atmospheric $\mathrm{CO}_{2}$ concentrations may modify leaf uptake of $\mathrm{O}_{3}$ and, hence, the risk for negative impacts on crops

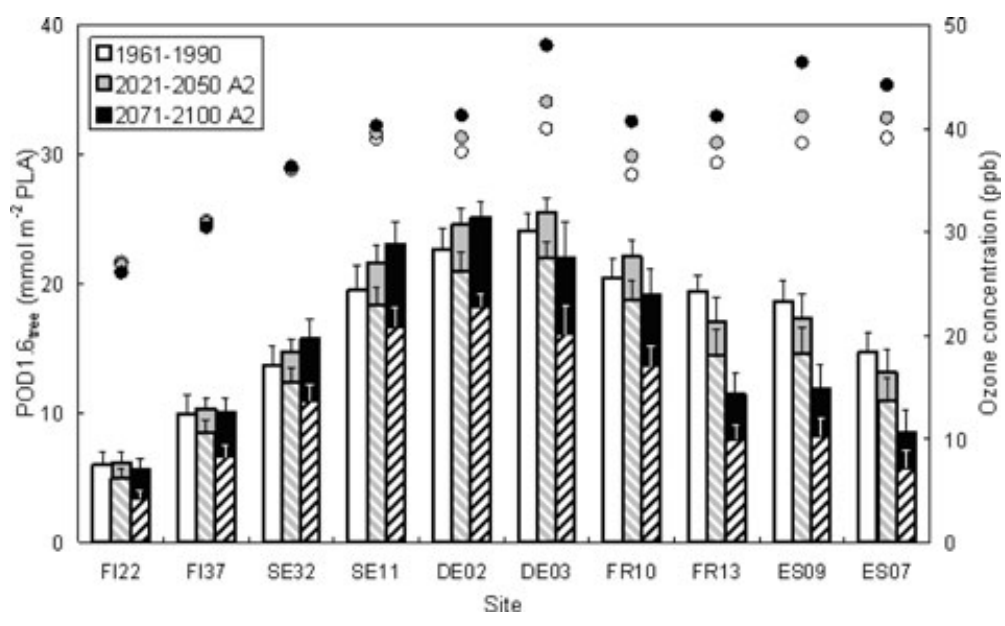

Fig. 6. Average phytotoxic $\mathrm{O}_{3}$ dose for a generic deciduous tree (POD1.6 $6_{\text {tree }}$ ) during 1961-1990, 2021-2050 and 2071-2100 following the SRES A2 emission scenario. The striped part of the bars show average POD1.6 tree when the $g_{\mathrm{s}}$ response function for $\mathrm{CO}_{2}\left(f_{\mathrm{CO}_{2}}\right)$ is included in the calculation. Error bars show standard deviation $(N=$ $30 \mathrm{yr}$ ). Circles are average $\mathrm{O}_{3}$ concentration (scale on the right) for the same time periods as POD1.6 $6_{\text {tree }}$ is accumulated. 
Fig. 7. Average phytotoxic $\mathrm{O}_{3}$ dose for a generic deciduous tree (POD1.6 $6_{\text {tree }}$ ) during 1961-1990, 2021-2050 and 2071-2100 following the SRES A2 emission scenario. Included in the POD1.6 $6_{\text {tree }}$ calculation is the $g_{\mathrm{s}}$ response function for $\mathrm{SWP}\left(f_{\mathrm{SWP}}\right)$, but not for $\mathrm{CO}_{2}\left(f_{\mathrm{CO}_{2}}\right)$. Error bars show standard deviation $(N=30 \mathrm{yr})$.

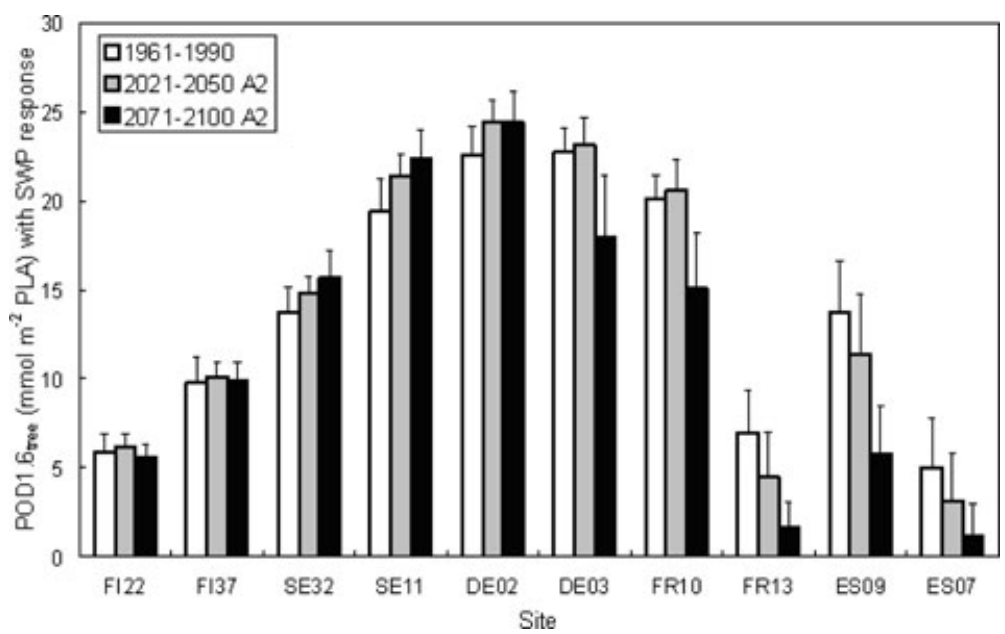

and forest trees. In agreement with earlier studies (Simpson and Emberson, 2006; Emberson et al., 2007; Simpson et al., 2007) the spatial flux-based risk pattern for $\mathrm{O}_{3}$ damage differed substantially from the AOT40-based risk, in the reference as well as future climate and irrespective of emission scenario (A2 or B2). It is important to take the influence of climate change into account in future risk assessment of surface $\mathrm{O}_{3}$, since factors such as warming, changes in amount and distribution of precipitation, shifts in growing season and elevated $\mathrm{CO}_{2}$ concentrations affect the stomatal uptake of $\mathrm{O}_{3}$ into the leaves (Harmens et al., 2007). Flux-based models are generally considered to be more physiologically relevant compared to exposure-based indices such as AOT40. The AOT40 index only reflects changes in the ambient $\mathrm{O}_{3}$ concentration, while the flux-based PODY index also allows climatic conditions and the $\mathrm{CO}_{2}$ concentration to modify stomatal uptake rates of $\mathrm{O}_{3}$, in line with important physiological mechanisms.

The results in this study clearly showed that the expected reduction in $g_{\mathrm{s}}$ with rising atmospheric $\mathrm{CO}_{2}$ concentrations is of large importance for the decrease in projected future flux-based $\mathrm{O}_{3}$ risk. Harmens et al. (2007) also showed that the reduced $g_{\mathrm{s}}$ under higher $\mathrm{CO}_{2}$ concentrations has the potential to significantly reduce the risk for $\mathrm{O}_{3}$ damage. For crops, there seem to be consensus among studies that plants growing under elevated $\mathrm{CO}_{2}$ concentrations have reduced $g_{\text {s }}$ (Bunce, 2000; Wall et al., 2000; Ainsworth and Rogers, 2007), but the magnitude of this effect under realistic agronomic conditions is less certain. For forests, $g_{\mathrm{s}}$ may not at all decrease with rising atmospheric $\mathrm{CO}_{2}$ concentrations in many tree species. In four out of five free-air $\mathrm{CO}_{2}$ enrichments experiments in closed forests, $g_{\mathrm{s}}$ was not significantly reduced under elevated $\mathrm{CO}_{2}$ concentrations (Ellsworth, 1999; Bernacchi et al., 2003 (pre-coppice canopy closure); Keel et al., 2007; Maier et al., 2008; Uddling et al., 2009; but see Gunderson et al., 2002 and Domec et al., 2009). In the long term, cumulative effects of elevated $\mathrm{CO}_{2}$ on plant growth and stand structure may be more important than the primary stomatal closure response to increased $\mathrm{CO}_{2}$ in determining $g_{\mathrm{s}}$ in closed forests (Uddling et al., 2008; Uddling et al., 2009).

In a flux-based risk assessment for pine, beech and oak during one year at three sites in Europe, Emberson et al. (2007) found phenology $\left(f_{\text {phen }}\right)$ and soil water $\left(f_{\mathrm{SWP}}\right)$ to be the key drivers limiting the seasonal profile of $\mathrm{O}_{3}$ flux. Tuovinen et al. (2009) emphasised the urgent need to develop soil moisture status modelling and its effect on $g_{\mathrm{s}}$ for forests (crops may be irrigated). In the base case of our results, soil moisture is assumed to never limit $g_{\mathrm{s}}$, mainly because of difficulties in estimating the plantrelevant soil water potential valid for the integrated rooting zone of vegetation inside an entire model grid. The simulation including $f_{\text {SWP }}$ for the generic deciduous tree indicated, however, that soil water deficits have the potential to limit stomatal uptake of $\mathrm{O}_{3}$ in southern Europe and that this limitation is likely to increase in the future (Fig. 7). The conversion (based on available data from RCA3) of mean soil water content to mean SWP across a $2.3 \mathrm{~m}$ soil profile may represent an oversimplification as it does not capture the vertical gradients in soil water status and its integrated, non-linear, effect on plant water availability. Therefore, the assessment of the impact of geographical differences and temporal changes in soil moisture on stomatal $\mathrm{O}_{3}$ flux presented here indicates directions rather than magnitudes of the likely effects.

Several studies have reported an earlier onset of spring and a prolongation of the growing season in mid and high latitudes associated with global warming (Linderholm, 2006; Menzel et al., 2006). Changes in the timing of the growing season were omitted in this study, which assumed a fixed growth interval based on latitude. For specific crops, such as wheat, cumulative exposure may decline in a warmer climate due to accelerated plant development (Fuhrer, 2009). An earlier start of the growing season for wheat could result in a reduced overlap between the $\mathrm{O}_{3}$ exposure accumulation period and the peak summer $\mathrm{O}_{3}$ levels (Harmens et al., 2007; Fuhrer, 2009). Conversely, an earlier growing season may lead to more frequent co-occurrence of 
sensitive stages and spring-time peaks in $\mathrm{O}_{3}$ in the northern part of the Nordic countries (Karlsson et al., 2007b; Klingberg et al., 2009). For the generic crop, the 3 month growing season, much longer than the approximately 55-d period of high $\mathrm{O}_{3}$ sensitivity for wheat (LRTAP Convention, 2004), allows the POD3 $3_{\text {crop }}$ index to be less sensitive to changes in the timing of the growing season and can be interpreted as maximum potential risk. For trees, the growth period, and thus the period of $\mathrm{O}_{3}$ uptake, is likely to be prolonged in a future warmer climate (Taylor et al., 2008), implying an underestimation of the future $\mathrm{O}_{3}$ risk in this assessment.

There are large uncertainties in both climate projections and parameters in models for $\mathrm{O}_{3}$ risk assessment, as pointed out by Fuhrer (2009). Leaf properties determining the rate of $\mathrm{O}_{3}$ uptake and the biochemical defence capacity can be modified by changes in temperature, air humidity, soil moisture and increasing $\mathrm{CO}_{2}$ concentration. $\mathrm{O}_{3}$ uptake calculations may only be accurate when applied under conditions representative of those under which the parameterisation was performed, increasing the uncertainty when extrapolating to future climatic conditions (Fuhrer, 2009). Ashmore (2005) requested the development of new models, linking stomatal flux and detoxification processes to carbon assimilation and allocation, to include the capacity of species to adapt to changes in nutrient and water availability. Also, Musselman et al. (2006) emphasized the need to consider detoxification mechanisms in flux-based models, but noted the large uncertainty in quantifying the various defence mechanisms in plants.

In this study, the current LRTAP Convention (2004) parameterisation of the $g_{\mathrm{s}}$ model indicated that $f_{\text {temp }}$ was considerably more important than $f_{\mathrm{VPD}}$ in limiting $\mathrm{O}_{3}$ uptake for the generic crop (Table 2) as well as for the generic tree at the northern sites (Table 4). This large importance of $f_{\text {temp }}$ compared to $f_{\mathrm{VPD}}$ in limiting $g_{\mathrm{s}}$ could be questioned, considering the fact that minimizing water loss is a main function of stomata. The bell shaped optimum curve of the temperature function for crops seems uncertain as it predicts complete stomatal closure at temperatures below $12^{\circ} \mathrm{C}$ and above $40^{\circ} \mathrm{C}$, which is hardly realistic for the Nordic and Mediterranean regions, respectively. Most physiological responses are known to acclimate to the prevailing temperature (e.g. Larcher, 2003; Körner, 2006) and both spatial (cold north vs. warm south) and temporal (during climate change) acclimation of the stomatal temperature response are thus likely. A certain degree of stomatal closure in response to low temperatures can be expected in colder conditions, but further evaluation of the stomatal temperature response function is required to improve predictions of the effect of climate on stomatal $\mathrm{O}_{3}$ flux. In addition, modelled stomatal $\mathrm{O}_{3}$ flux strongly depends on the quality of the $g_{\max }$ value (Fuhrer, 2009), which differs significantly between species and is likely to depend on climatic region.

The PODY calculations are strongly dependent on the quality of the input data. The coarse spatial resolution of regional climate models $\left(50 \times 50 \mathrm{~km}^{2}\right)$ limits the details of important processes, such as diurnal range and extremes. Local scale characteristics, e.g. promoting nighttime air temperature inversions, may cause large diurnal $\mathrm{O}_{3}$ range deviating from the average conditions of the model grid (Klingberg et al., 2008). The large underestimation of VPD in RCA3 $(-43 \%$ bias on average for the five northernmost sites) is of special concern for the stomatal $\mathrm{O}_{3}$ uptake calculations and may cause an overestimation of the flux-based $\mathrm{O}_{3}$ risk (Table 3). The importance of representative diurnal dynamics in temperature and VPD is emphasized when regional scale modelled data are used for stomatal $\mathrm{O}_{3}$ uptake calculations. Klingberg et al. (2008) estimated the sensitivity of POD0 and POD6 calculations for potato to small changes in input data in more detail for a site in southwest Sweden. A $10 \%$ change in $\mathrm{O}_{3}$ and temperature resulted in approximately $20 \%$ and $34-40 \%$ change in POD6, respectively. Without the flux threshold (POD0), the change was smaller. The sensitivity to a $10 \%$ change in VPD was much smaller (3-5\% change in POD), but it was concluded that this factor presumably plays a much greater role in drier conditions. Other important simplifications are that the land-cover does not change with changing climate in MATCH and that meteorology is only based on one set-up of the climate model.

The uncertainties discussed above result in considerably uncertainty in the exact value of the stomatal $\mathrm{O}_{3}$ fluxes reported here. The most important uncertainties are considered to be the projections of future atmospheric changes and the parameterisation of the stomatal $\mathrm{O}_{3}$ flux model, neglecting both spatial and temporal acclimation and adaptation. More research is required to reduce the uncertainties before projected POD $3_{\text {crop }}$ and POD1.6 $6_{\text {tree }}$ can be used to give reasonable estimates of European yield or growth loss due to $\mathrm{O}_{3}$ damage. This study does therefore not intend to predict European yield or growth losses due to $\mathrm{O}_{3}$ damage in the future. The flux-based approach is, however, an improvement compared to AOT40. Notwithstanding the mentioned uncertainties we believe that there is high confidence in the general pattern and directions of change obtained in this study of how future climatic conditions will influence the $\mathrm{O}_{3}$ risk for vegetation in Europe.

\section{Conclusions}

- The increase in modelled future surface $\mathrm{O}_{3}$ concentrations is large in southern Europe, despite constant precursor emissions in MATCH. However, the future stomatal $\mathrm{O}_{3}$ uptake remain unchanged or decrease at most sites for a generic crop and decrease at all sites for a generic deciduous tree, mainly as a result of the modelled reduction in stomatal conductance with rising atmospheric $\mathrm{CO}_{2}$. Drier air and high soil moisture deficit as well as high temperatures are also important in southern Europe. However, if the $\mathrm{CO}_{2} g_{\mathrm{s}}$ response function is excluded from the analysis, which may be realistic for forest trees (Uddling et al., 2009 and references therein), the future 
stomatal $\mathrm{O}_{3}$ flux is reduced only in southern Europe for the generic deciduous tree.

- The largest flux-based $\mathrm{O}_{3}$ risk for a generic crop and a generic deciduous tree is found at the central European sites, in both the reference and projected future climate. This pattern differs substantially from the concentration-based AOT40 index, indicating largest $\mathrm{O}_{3}$ risk in southern Europe.

- According to the current $g_{\mathrm{s}}$ model parameterisation, the temperature function limits the stomatal $\mathrm{O}_{3}$ flux in northern Europe considerably, while the VPD and SWP functions are important mainly in southern Europe.

- This study demonstrates the importance to account for the climatic and atmospheric $\mathrm{CO}_{2}$ influences on stomatal $\mathrm{O}_{3}$ uptake for improved risk assessment in a changing atmosphere and climate.

\section{Acknowledgments}

Thanks are due to Patrick Samuelsson and Barry Broman at the Rossby Centre for providing climate data in a suitable format. Thanks are also due to the research programme Climate Change and Environmental Objectives (CLEO), funded by the Swedish Environmental Protection Agency, for supporting the work by Per Erik Karlsson, Magnuz Engardt and Håkan Pleijel.

\section{References}

Ainsworth, E. A. and Rogers, A. 2007. The response of photosynthesis and stomatal conductance to rising $\left[\mathrm{CO}_{2}\right]$ : mechanisms and environmental interactions. Plant Cell Environ. 30, 258-270.

Andersson, C. and Engardt, M. 2010. European ozone in a future climate: importance of changes in dry deposition and isoprene emissions. $J$. Geophys. Res.-Atmos. 115, D02303. doi: 10.1029/2008JD011690.

Andersson, C., Langner, J. and Bergström, R. 2007. Interannual variation and trends in air pollution over Europe due to climate variability during 1958-2001 simulated with a regional CTM coupled to the ERA40 reanalysis. Tellus 59B, 77-98.

Ashmore, M., Emberson, L., Karlsson, P. E. and Pleijel, H. 2004. New directions: a new generation of ozone critical levels for the protection of vegetation in Europe. Atmos. Environ. 38, 2213-2214.

Ashmore, M. R. 2005. Assessing the future global impacts of ozone on vegetation. Plant Cell Environ. 28, 949-964.

Bernacchi, C. J., Calfapietra, C., Davey, P. A., Wittig, V. E., ScarasciaMugnozza, G. E. and co-authors. 2003. Photosynthesis and stomatal conductance responses of poplars to free-air $\mathrm{CO}_{2}$ enrichment (PopFACE) during the first growth cycle and immediately following coppice. New Phytol. 159, 609-621.

Bunce, J. A. 2000. Responses of stomatal conductance to light, humidity and temperature in winter wheat and barley grown at three concentrations of carbon dioxide in the field. Global Chang. Biol. 6, 371-382.

Dentener, F., Stevenson, D., Ellingsen, K., van Noije, T., Schultz, M. and co-authors. 2006. The global atmospheric environment for the next generation. Environ. Sci. Technol. 40, 3586-3594.

Derwent, R. G., Simmonds, P. G., Manning, A. J. and Spain, T. G. 2007. Trends over a 20-year period from 1987 to 2007 in surface ozone at the atmospheric research station, Mace Head, Ireland. Atmos. Environ. 41, 9091-9098.

Domec, J. C., Palmroth, S., Ward, E., Maier, C. A., Thérézien, M. and Oren, R. 2009. Acclimation of leaf hydraulic conductance and stomatal conductance of Pinus taeda (loblolly pine) to long-term growth in elevated $\mathrm{CO}_{2}$ (free-air $\mathrm{CO}_{2}$ enrichment) and $\mathrm{N}$-fertilization. Plant Cell Environ. 32, 1500-1512.

Ellsworth, D. S. 1999. $\mathrm{CO}_{2}$ enrichment in a maturing pine forest: are $\mathrm{CO}_{2}$ exchange and water status in the canopy affected? Plant Cell Environ. 22, 461-472.

Emberson, L., Simpson, D., Tuovinen, J. P., Ashmore, M. and Cambridge, H. M. 2000a. Towards a model of ozone deposition and stomatal uptake over Europe. EMEP MSC-W Note 6/2000. Norwegian Meteorological Institute, Oslo, Norway. Available at: www.emep.int. Emberson, L. D., Ashmore, M. R., Cambridge, H. M., Simpson, D. and Tuovinen, J. P. 2000b. Modelling stomatal ozone flux across Europe. Environ. Pollut. 109, 403.

Emberson, L. D., Büker, P. and Ashmore, M. R. 2007. Assessing the risk caused by ground level ozone to European forest trees: a case study in pine, beech and oak across different climate regions. Environ. Pollut. 147, 454-466.

Engardt, M., Bergström, R. and Andersson, C. 2009. Climate and emission changes contributing to changes in near-surface ozone in Europe over the coming decades-results from model studies. Ambio 38, $452-458$.

Fuhrer, J. 2009. Ozone risk for crops and pastures in present and future climates. Naturwissenschaften 96, 173-194.

Grant, C. D., Groenevelt, P. H. and Robinson, N. I. 2010. Application of the Groenevelt-Grant soil water retention model to predict the hydraulic conductivity. Aust. J. Soil Res. In press.

Groenevelt, P. H. and Grant, C. D. 2004. A new model for the soil-water retention curve that solves the problem of residual water contents. Eur. J. Soil Sci. 55, 479-485.

Gunderson, C. A., Sholtis, J. D., Wullschleger, S. D., Tissue, D. T., Hanson, P. J. and co-authors. 2002. Environmental and stomatal control of photosynthetic enhancement in the canopy of a sweetgum ( Liquidambar styraciflua L.) plantation during 3 years of $\mathrm{CO}_{2}$ enrichment. Plant Cell Environ. 25, 379-393.

Hall, D. G. M., Reeve, M. J., Thomson, A. J. and Wright, V. F. 1977. Water retention, porosity and density of field soils. Technical Monograph No 9. Soil Survey, Rothhamstead Experimental Station, UK.

Harmens, H., Mills, G., Emberson, L. D. and Ashmore, M. R. 2007. Implications of climate change for the stomatal flux of ozone: a case study for winter wheat. Environ. Pollut. 146, 763-770.

Hayes, F., Mills, G., Harmens, H. and Norris, D. 2007. Evidence of Widespread Ozone damage to Vegetation in Europe (1990-2006). Programme Coordination Centre for the ICP Vegetation, Centre for Ecology and Hydrology, UK, pp. 58. Available at: http://icpvegetation.ceh.ac.uk.

Häggmark, L., Ivarsson, K. I., Gollvik, S. and Olofsson, R. O. 2000. MESAN, an operational mesoscale analysis system. Tellus 52A, 220.

Jacob, D. J. and Winner, D. A. 2009. Effect of climate change on air quality. Atmos. Environ. 43, 51-63.

Jarvis, P. G. 1976. The interpretation of the variations in leaf water potential and stomatal conductance found in canopies in the field. Phil. Trans. R. Soc., Lond., B 87, 593-610. 
Jones, H. G. 1992. Plants and Microclimate. A Quantitative Approach to Environmental Plant Physiology. 2nd Edition. Cambridge University Press, Cambridge, pp. 428.

Karlsson, P. E., Braun, S., Broadmeadow, M., Elvira, S., Emberson, L. and co-authors. 2007a. Risk assessments for forest trees: the performance of the ozone flux versus the AOT concepts. Environ. Pollut. 146, 608-616.

Karlsson, P. E., Tang, L., Sundberg, J., Chen, D., Lindskog, A. and co-authors. 2007b. Increasing risk for negative ozone impacts on vegetation in northern Sweden. Environ. Pollut. 150, 96-106.

Keel, S. G., Pepin, S., Leuzinger, S. and Korner, C. 2007. Stomatal conductance in mature deciduous forest trees exposed to elevated $\mathrm{CO}_{2}$. Trees 21, 151-159.

Kjellström, E., Bärring, L., Gollvik, S., Hansson, U., Jones, C. and coauthors. 2005. A 140-year simulation of European climate with the new version of the Rossby Centre regional atmospheric climate model (RCA3). In: SMHI Reports Meteorology and Climatology No. 108. SMHI, SE-60176 Norrköping, Sweden, 54.

Klingberg, J., Danielsson, H., Simpson, D. and Pleijel, H. 2008. Comparison of modelled and measured ozone concentrations and meteorology for a site in south-west Sweden: implications for ozone uptake calculations. Environ. Pollut. 155, 99-111.

Klingberg, J., Björkman, M. P., Pihl Karlsson, G. and Pleijel, H. 2009. Observations of ground-level ozone and $\mathrm{NO}_{2}$ in northernmost Sweden, including the Scandian Mountain Range. Ambio 38, 448-451.

Körner, C. 2006. Significance of temperature in plant life. In: Plant Growth and Climate Change (eds J. I. L. Morison and M. D. Morecraft), Blackwell Publishing, Oxford, UK, 48-69.

Langner, J., Bergström, R. and Foltescu, V. 2005. Impact of climate change on surface ozone and deposition of sulphur and nitrogen in Europe. Atmos. Environ. 39, 1129-1141.

Larcher, W. 2003. Physiological Plant Ecology. 4th Edition, SpringerVerlag, Berlin, Germany, 513.

Linderholm, H. W. 2006. Growing season changes in the last century. Agric. Forest Meteorol. 137, 1-14.

LRTAP Convention 2004. Manual on methodologies and criteria for Modelling and Mapping Critical Loads \& Levels and Air Pollution Effects, Risks and Trends. Updated August 2008. Available and continuously updated at: www.icpmapping.org.

Maier, C. A., Palmroth, S. and Ward, E.. 2001. Short-term effects of fertilization on photosynthesis and leaf morphology of field-grown loblolly pine following long-term exposure to elevated $\mathrm{CO}_{2}$ concentration. Tree Physiol. 28, 597-606.

Medlyn, B. E., Barton, C. V. M., Broadmeadow, M. S. J., Ceulemans, R., De Angelis, P. and co-authors. 2001. Stomatal conductance of forest species after long-term exposure to elevated $\mathrm{CO}_{2}$ concentration: a synthesis. New Phytol. 149, 247-264.

Meleux, F., Solmon, F. and Giorgi, F. 2007. Increase in summer European ozone amounts due to climate change. Atmos. Environ. 41, 7577-7587.

Menzel, A., Sparks, T. H., Estrella, N., Koch, E., Aaasa, A. and coauthors. 2006. European phenological response to climate change matches the warming pattern. Global Chang. Biol. 12, 1969-1976.

Monteith, J. and Unsworth, M. H. 2008. Principles of Environmental Physics. 3rd Edition. Academic Press, London, 418.

Musselman, R. C., Lefohn, A. S., Massman, W. J. and Heath, R. L. 2006. A critical review and analysis of the use of exposure- and flux-based ozone indices for predicting vegetation effects. Atmos. Environ. 40, 1869-1888.

Nakicenovic, N., Alcamo, J., Davis, G., Vries, B.d., Fenhann, J. and co-authors. 2000. Emission Scenarios: A special report of IPCC Working Group III. Cambridge University Press, Cambridge, UK, 599.

Pleijel, H., Danielsson, H., Vandermeiren, K., Blum, C., Colls, J. and coauthors. 2002. Stomatal conductance and ozone exposure in relation to potato tuber yield-results from the European CHIP programme. Eur. J. Agron. 17, 303-317.

Pleijel, H., Danielsson, H., Ojanpera, K., Temmerman, L. D., Hogy, P. and co-authors. 2004. Relationships between ozone exposure and yield loss in European wheat and potato-a comparison of concentration- and flux-based exposure indices. Atmos. Environ. 38, 2259-2269.

Pleijel, H., Danielsson, H., Emberson, L., Ashmore, M. R. and Mills, G. 2007. Ozone risk assessment for agricultural crops in Europe: further development of stomatal flux and flux-response relationships for European wheat and potato. Atmos. Environ. 41, 3002-3040.

Prather, M., Gauss, M., Berntsen, T., Isaksen, I., Sundet, J. and coauthors. 2003. Fresh air in the $21^{\text {st }}$ century? Geophys. Res. Lett. 30, 1100. doi: 10.1029/2002GL016285.

Robertson, L., Langner, J. and Engardt, M. 1999. An Eulerian limitedarea atmospheric transport model. J. Appl. Meteorol. 38, 190210.

Simpson, D. and Emberson, L. 2006. Ozone fluxes-updates, chapter 5 in EMEP status report 1/2006, Transboundary acidification, eutrophication and ground level ozone in Europe since 1990 to 2004. Available at: www.emep.int.

Simpson, D., Ashmore, M. R., Emberson, L. and Tuovinen, J. P. 2007. A comparison of two different approaches for mapping potential ozone damage to vegetation. A model study. Environ. Pollut. 146, 715725 .

Sitch, S., Cox, P. M., Collins, W. J. and Huntingford, C. 2007. Indirect radiative forcing of climate change through ozone effects on the landcarbon sink. Nature 448, 791-794.

Stevenson, D. S., Dentener, F. J., Schultz, M. G., Ellingsen, K., van Noije, T. P. C. and co-authors. 2006. Multimodel ensemble simulations of present-day and near-future tropospheric ozone. J. Geophys. Res.Atmos. 111, D08301. doi: 10.1029/2005JD006338.

Taylor, G., Tallis, M. J., Giardina, C. P., Percy, K. E., Miglietta, F. and co-authors. 2008. Future atmospheric $\mathrm{CO}_{2}$ leads to delayed autumnal senescence. Global Change Biol. 14, 264-275.

The Royal Society 2008. Ground-level ozone in the $21^{\text {st }}$ century: future trends, impacts and policy implications. RS Policy document 15/08, London, pp. 133. Available at: http://royalsociety.org/ displaypagedoc. .asp?id $=31506$.

Tilmes, S., Brandt, J., Flatoy, F., Bergström, R., Flemming, J. and coauthors. 2002. Comparison of five eulerian air pollution forecasting systems for the summer of 1999 using the German ozone monitoring data. J. Atmos. Chem. 42, 91-121.

Tuovinen, J. P., Simpson, D., Emberson, L., Ashmore, M. and Gerosa, G. 2007. Robustness of modelled ozone exposures and doses. Environ. Pollut. 146, 578-586.

Tuovinen, J. P., Emberson, L. and Simpson, D. 2009. Modelling ozone fluxes to forests for risk assessment: status and prospects. Ann. For. Sci. 66, 401. 
Uddling, J., Gunthardt-Goerg, M. S., Matyssek, R., Oksanen, E., Pleijel, H. and co-authors. 2004. Biomass reduction of juvenile birch is more strongly related to stomatal uptake of ozone than to indices based on external exposure. Atmos. Environ. 38, 4709-4719.

Uddling, J., Teclaw, R. M., Kubiske, M. E., Pregitzer, K. S. and Ellsworth, D. S. 2008. Sap flux in pure aspen and mixed aspenbirch forests exposed to elevated concentrations of carbon dioxide and ozone. Tree Physiol. 28, 1231-1243.

Uddling, J., Teclaw, R. M., Pregitzer, K. S. and Ellsworth, D. S. 2009. Leaf and canopy conductance in aspen and aspen-birch forests under free-air enrichment of carbon dioxide and ozone. Tree Physiol. 29, 1367-1380.

Van Dingenen, R., Dentener, F. J., Raes, F., Krol, M. C., Emberson, L. and co-authors. 2009. The global impact of ozone on agricultural crop yields under current and future air quality legislation. Atmos. Environ. 43, 604-618.

van Loon, M., Vautard, R., Schaap, M., Bergström, R., Bessagnet, B. and co-authors. 2007. Evaluation of long-term ozone simulations from seven regional air quality models and their ensemble. Atmos. Environ. 41, 2083-2097.

Vingarzan, R. 2004. A review of surface ozone background levels and trends. Atmos. Environ. 38, 3431-3442.
Wall, G. W., Adam, N. R., Brooks, T. J., Kimball, B. A., Pinter, P. J. and co-authors. 2000. Acclimation response of spring wheat in a free-air $\mathrm{CO}_{2}$ enrichment (FACE) atmosphere with variable soil nitrogen regimes. 2. Net assimilation and stomatal conductance of leaves. Photosyn. Res. 66, 79-95.

Wall, G. W., Garcia, R. L., Kimball, B. A., Hunsaker, D. J., Pinter, P. J. and co-authors. 2006. Interactive effects of elevated carbon dioxide and drought on wheat. Agron. J. 98, 354-381.

\section{Supporting Information}

Additional supporting information may be found in the online version of this article:

Appendix S1: POD $3_{\text {crop }}$ following the B2 scenario. Appendix S2: POD1.6 $6_{\text {tree }}$ following the B2 scenario.

Please note: Wiley-Blackwell are not responsible for the content or functionality of any supporting materials supplied by the authors. Any queries (other than missing material) should be directed to the corresponding author for the article. 